(C) Sean Gaston, published in Angelaki 7.3 (2002): 105-118

\title{
Derrida and the Ruins of Disinterest
}

\section{Disinterest on the Margins?}

Can the question of disinterest be addressed to Derrida's work? Can it be addressed to a work that has sought to challenge the traditional determinations, boundaries, "internal" economies and "necessary" marginalisations that define Western philosophy? As Derrida has pointed out, the question of disinterest has a significant place in the institutional history of philosophy as an academic discipline in France. In "The Principle of Reason: The University in the Eyes of its Pupils" (1983), he notes that in the French Universities "la philosophie" has traditionally been designated as "disinterested research" [recherche désintéressée], that is, as "the disinterested [désintéressé] exercise of reason, under the sole authority of the principle of reason" ("Les pupilles de l'Université" 479-80, my trans.). ${ }^{1}$

Derrida has rarely used the word disinterest or, as Lévinas, redefined it to mark a radical challenge to the interests of being. ${ }^{2}$ Nonetheless, the question of disinterest appears on the margins of Derrida's principal essays on Lévinas. In "Violence and Metaphysics" (1964), he makes a passing, but telling, reference to Greek "philosophy's apparent disinterest" [le désintéressement apparent de la philosophie] ( 97; "Violence et métaphysique" 145). In "At This Very Moment in This Work Here I am" (1980), he cites a passage from an essay on 
Lévinas by Catherine Chalier in which she speaks of "eschatological disinterestedness" [le désintéressement eschatologique] (42; "En ce moment même"196). ${ }^{3}$ In a footnote to Adieu (1997), he quotes a passage from Lévinas's De Dieu qui vient à l'idée that includes the phrase “dés-intér-essement" (180 n. 2). ${ }^{4}$ Derrida's lack of interest in Lévinas's reworking of disinterestedness is perhaps due to the fact that, as "Violence and Metaphysics" suggests, he would not follow Lévinas in drawing or maintaining an absolute distinction or difference between interest (totality) and disinterest (infinity). Dés-intéressement - "desire of an other order than those of affectivity and hedonistic activity .... desire without end, beyond Being: dés-intéressement, transcendence - desire of the Good [désir du Bien]" belongs to the rich and profound philosophy of Lévinas ("Dieu et la philosophie” 111, my trans.).

The narrator in Derrida's "Envois" (1980) says at one point, "I believe in no disinterestedness" [je ne crois à aucun désintéressement] and on the few occasions when Derrida speaks of disinterest it is more often than not to warn of a concealed economy of interest behind any proclamation of disinterest $(206 ; 221)$. As he writes in "Plato's Pharmacy” (1968), “one must always, in the symptomatological manner of Nietzsche, be careful to diagnose the economy, the investment and deferred benefit behind the sign of pure renunciation or the bidding of disinterested sacrifice" [la mise du sacrifice désintéressé] (120; “La pharmacie de Platon” 137). ${ }^{5}$

Unsurprisingly, Derrida has the most to say about disinterest as an economy of interest in his essays on Kant's Critique of Judgement. In The Truth in Painting (1978), he defines Kantian disinterest as "the question of a detachment" (39). Kant's insistence that "all interest consists" in "a pleasure in the real existence of an object" leads Derrida to characterise Kantian "pure disinterested delight" [le plaire pur et désintéressé, uninteressirten Wohlgefallen] as "the neutralization, not simply the putting to death [la mise à mort] but the mise en crypte of all that exists in as much as it exists" (Kant 43-44, 154; The Truth in Painting 46; La Vérité en peinture 54). As he says, "like a sort of transcendental reduction," 
this absolute disinterestedness leaves a subjectivity that "is not an existence, nor even a relation to existence. It is an inexistent or anexistent subjectivity" $(44,46)$. Derrida similarly reads the claims of pure disinterested delight of the individual "to subjective universality" in $\S 6$ as the unavoidable intervention of the "entirely-other" (Kant 51; The Truth in Painting 47). ${ }^{6}$ Pure disinterested delight or, the "autoaffection" of "I-please-myself-in" [le se-plaireà], "immediately goes outside its inside: it is pure heteroaffection." Kant's idea of subjective universality reveals that the "most irreducible heteroaffection inhabits - intrinsically - the most closed autoaffection" (The Truth in Painting 47; La Vérité en peinture 55).

In "Economimesis" (1975), Derrida argues that for Kant "the most moral and the most true, the most present disinterested pleasure" [le plaisir désintéressé] is produced by "poetic speech" [la parole poétique] which ultimately transforms "hetro-affection into auto-affection, producing the maximum disinterested pleasure" [plaisir désintéressé] (83-84, my trans.). For Derrida, disinterested pleasure, the "Wohlegefallen désintéressé," is produced and enclosed within "the auto-affective circle of mastery or reappropriation." He concludes that the Kantian idea of disinterest has an overriding "interest in determining the other as its other" [intérêt à déterminer l'autre comme son autre] $(77,89,92) .^{7}$

If the question of disinterest and particularly the question of the disinterest of the subject is addressed to Derrida's work, one should perhaps ask if such a "disinterest," if it were possible, would be a strategy of repetition or of rupture? In "The Ends of Man" (1968), Derrida writes:

A radical trembling can only come from the outside ... But the "logic" of every relation to the outside is very complex and surprising. It is precisely the force and the efficiency of the system that regularly change transgressions into "false exits." Taking into account these effects of the system, one has nothing, from inside where "we are," but the choice between two strategies: 
a. To attempt an exit and a deconstruction without changing terrain, by repeating [en répétant] what is implicit in the founding concepts and the original problematic, by using against the edifice the instruments or stones available in the house, that is, equally, in language ...

b. To decide to change terrain, in a discontinuous and irruptive fashion [manière discontinue et irruptive], by brutally placing oneself outside, and by affirming an absolute break [la rupture] and difference (134-35; "Le fins de l'homme" 162).

Does a radical "disinterest," that is somehow at once more than and less than an economy of interest, presume to divest the subject of its interests (in its self as its self, its self presence, its chez soi, its interest in the colonisation of the other) through repeating, displacing and dislocating these interests or through an absolute rupture or breaking free from the interests of the subject? Both strategies, Derrida warns, have their respective "risks" of consolidation or blind reinstatement. There is, he says, no "simple and unique" choice to be made between these two strategies. "If," he concludes, "there is style" - and we would add a style of any radical "disinterest" - "it must be plural" (134-35; "les find de l'homme" 162-63).

Since Descartes, at least, the problem of the private sphere has always been attended by discourses of disinterest. In this sense, one could say that disinterest belongs to the postCartesian tradition of the Cogito and subjectivity. Though it could be associated with indifference or disadvantage, disinterest was commonly understood as an opposite of selfinterest, as a positive quality opposed to the exclusive rights and claims of private interest and judgement. To be disinterested was to recognise a public interest or good beyond selfinterest and to be able to judge impartially between our own interests and the interests of others. Disinterest has always been caught up within the problem of how one contains, manages and guides subjectivity. 
On the one hand, disinterest can be seen, in the Husserlian sense, as a phenomenon of the subject: a discourse that has always been tied to a question of "the consciousness of something." On the other hand, after Descartes, disinterest was (at least in Britain) by and large claimed as a discourses of the empiricists and defined by the attempt to find a stable point of reference outside of the subject to secure the disinterested subject. It is perhaps only after the thinkers of the late eighteenth century tried to find the ground for disinterest in the subject and that this culmination of disinterest signalled its collapse in the eventual recognition that neither the subject nor the external world could provide any reliable grounds for the disinterested subject - it is perhaps only after this transformation of the classical discourses of disinterest, that it was possible to think of the failure of disinterest as a radical dis-interest of the subject.

However, can any "radical" disinterest resist the interests of the Hegelian Aufhebung? As Derrida says in Glas (1974), for Hegel, "what denies and cuts subjectivity from itself [coupe la subjectivité d'elle-même] is also what raises and accomplishes it" (12-13; Glas 19). In the Hegelian system, "what is sublated is at the same time preserved" (Hegel 106). The Aufhebung is the engine of history as spirit in which "the soul ... rises to spirit through the intermediary of consciousness" (Hyppoilite 11). Derrida challenges the Hegelian history as spirit by translating Aufhebung as relève, "combining," he notes, "the senses in which one can be both raised in one's functions and relieved of them [être à la fois élevé et relevé de ses fonctions], replaced in a kind of promotion" ("The Pit and the Pyramid" 88; "Le puits et la Pyramide"102). The re- of re-lever (mis/re)translates auf-heben, marking a repetition, an indefinite re-placement as displacement, a remainder, an irreducible difference, that cannot be fully recouped or returned within the Hegelian project.

If Derrida identifies Hegelian "disinterest" as the essence of "interest" (of the dream of an absolute interest in the self, by itself of itself: auto-affection, présence à soi) and transforms it, disables it - can this transformation be described as a certain dis-interest? The gap 
between the prefix dis- and interest suggests a divesting, a reversal or removal of interest that does not have its origins in the self as such, in the interests of the self, especially in the interests of the self to be, in good conscience, a disinterested subject. "One must avoid good conscience at all costs," Derrida writes (Aporias 19). Can a certain dis-interest avoid good conscience? Is such a dis-interest of the subject, as opposed to a disinterest $b y$ the subject possible, a disinterest of the subject despite the subject - "malgré moi," as Lévinas says ("Dieu et la philosophie"118)? And how can such a dis-interest be addressed to Derrida's work?

\section{Privé/Public and the Secret}

My honor is interested, and, to mention a great secret, the reward is enormous (Poe 334).

Disinterest has never simply been a question of the disinterest of the subject. The traditional discourses of disinterest (in other words, discourses of disinterest after Descartes and before Nietzsche) can broadly be defined as the ongoing attempt to find a point of reference to mediate between the equivocal demands of the public and the private spheres. Disinterest has never merely been a discourse of the private or of the public. There have always been discourses of disinterest, driven by the troubled recognition of the uncertain and unequal demands of both the public and the private. Classical discourses of disinterest are distinguished by the conviction that a point of reference or framework can be found to mediate between the public and the private.

In Totality and Infinity (1961), Lévinas gives the secret an exemplary role in mediating between the rights of the private individual and the demands of the public world. According to Lévinas, "separation is radical only if each being has its own time, that is, its interiority." 
Interiority enables "each being" to resist "universal time" and to "withstand totalization" (ibid. 57). Interiority "institutes an ... order where everything is pending" (ibid. 55). The inherent "discontinuity of the inner life interrupts historical time" (ibid.). Lévinas insists:

The real must not only be determined in its historical objectivity, but also from interior intentions, from the secrecy that interrupts the continuity of historical time. Only on the basis of this secrecy is the pluralism of society possible. It attests this secrecy (ibid. 57-8).

Secrecy, the secret, is the critical attribute of interiority, of the irreducible singularity of "each being." The secret is the mark of the independence of the "private individual" from the public sphere (the state, from a realm dominated by the universal, history, historical objectivity). The secret is indicative of the fundamental discontinuity of the private sphere in relation to the "continuity" of the public domain (ibid. 197). The secret is the only possibility for a pluralist society. The pluralist society "attests" - manifests - bears witness to the secret. Lévinas reinforces the central role played by the secret in the relation between the individual and the public world when he insists, "multiplicity can be produced only if the individuals retain their secrecy" (ibid. 120).

Does the role played by the secret in Lévinas's work have any parallel in Derrida's many writings on the secret and on the relation between the public and the private? To begin to explore this question, I would like to take a somewhat aphoristic look at a number of the "private" letters that have been made public in Derrida's essay "Envois," while also alluding to a number of his other, more recent, works.

1. In "Envois," the narrator wanders around the question of the public and the private and gestures towards connections between the secret, testimony, the witness and the public and the private. As with many of Derrida's texts, "Envois" can be seen as part of an ongoing dialogue with Lévinas. Derrida notes in Adieu, "one of the themes of recurrent analysis" in 
his essays on Lévinas has been the problematic status and role played by the "third party" (64 n. 1, my trans.). In "Force of Law"(1990), without referring directly to Lévinas (whom he does, nonetheless, mention some pages later), Derrida summarises a fundamental problem of the "third party": "I cannot speak the language of the other except to the extent that I appropriate it and assimilate it according to the law of an implicit third" [le loi d'un tiers implicite $](17$; Force de loi 40$){ }^{8}$ "Envois" can be seen as in part a reflection on the problem of the third party. Early in the text, the letter writer / narrator says:

I would like to write you so simply, so simply, so simply. Without having anything ever catch the eye, excepting yours alone, and what is more while erasing all the traits, even the most inapparent ones, the ones that mark the tone, or the belonging to a genre (the letter for example, or the post card), so that above all the language remains self-evidently secret if it were being invented at every step, and as if it were burning immediately, as soon as any third party [un tiers] would set eyes on it ("Envois" 11; "Envois" 15).

"For there are third parties, in the place where we are" (il ya des tiers, au lieu où nous sommes), the narrator later says (ibid. 46; 52).

2. The narrator states his (or her?) interests: "At bottom I am only interested in what cannot be sent off, cannot be dispatched in any case" [ne m'intéresse au fond que ce qui ne s'expédie pas, ne se dépêche en aucun cas]. The narrator goes on to relate how he meets "a young student" who asks him "why don't I kill myself” (ibid. 14-5; 19). He answers by highlighting the acute interest of this question:

I answered with a pirouette, I'll tell you, by sending him back his question, by signifying to him that he must have been savouring, along with me, the interest that he visibly was taking [l'intérêt qu'il prenait visiblement], at this 
very moment, in this question that I moreover concerned myself with along with others, among them myself. In private [je m'occupais par ailleurs avec d'autres, dont moi. En privé] (ibid. 14-5; 19).

The "young student" is "savouring ... the interest" in "this question" that the narrator is concerned with "[i]n private." The narrator is also savouring the interest that the student is taking in this very private question, this question of the private. He does not answer the student's question; he pirouettes and sends it back to him. Having stated that his interest lies in what "cannot be sent off," the narrator relates a story in which "the interest" in a private question "cannot be sent off," cannot be delivered. The narrator sends back the student's question: he does not return "the interest" taken in what is "private."

Can the narrator's playful rebuke be taken as an indication of a certain limitation, that the private, and the interest taken in the private, resists the savour, the relish, the craving of others, of the public? On the other hand, perhaps this story illustrates the continual, ongoing invasion of the private sphere. On the same day, the narrator says, "Do people ... realize to what extent this old couple [Socrates and Plato] has invaded our most private domesticity, mixing themselves up in everything" [notre domesticité la plus privée, se mêlant de tout]. A few sentences above this, he describes the interest of "this old couple" as an interest in paralysis: Socrates and Plato "were both very interested" [les intéresserait beaucoup] in the stingray, "this paralyzing animal" (ibid. 18; 23). The young student's question is of course not just any question. It is a question about the narrator's death. In Aporias (1993), Derrida writes:

death is always the name of a secret, since it signs the irreplaceable singularity. It puts forth the public name, the common name of a secret, the common name of the proper name without name. It is therefore always a shibboleth, for the manifest name of a secret is from the beginning a private 
name [le nom privé], so that language about death is nothing but the long history of a secret society, neither public nor private, semi-private, semipublic, on the border between the two (74).

3. In French, the word for private [privé] is the same as the word for deprived [privé]. The private can always be (mis)read as a privation or deprivation, a lack, absence or dispossession. The private can be understood as the lamentable absence of the public, which is how Hobbes (with the exception perhaps of the question of faith) understood disinterest. Hobbes believed that disinterest is only possible when a public institution or structure provides a reliable framework for disinterest outside of the subject: a public dis-interest of the private. ${ }^{9}$ If the private can be (mis)read as a privation or absence of the public, can it also be seen as a deprivation or dispossession? How can the private be a dispossession? A dispossession of what? To be the private, the private cannot have already possessed the public. To be private [privé] and to be deprived, dispossessed [privé], the private must be (mis)read as a dispossession of itself. The private dispossess itself of itself as it is private.

Is this dispossession of the private as it becomes private the trace of an impossible "secret without measure"? Is this dispossession a kind of original dis-interest of the private? Or, is it the indication of an impossible desire for an absolutely private dis-interest of the private? The narrator (and the translator) in "Envois" seem to allude some of these possibilities when he says,

I am the privé [the private, the deprived one], more than anyone else henceforth ... so then the privé of everything [Je suis le privé ... alors "privé" de tout $]$... I was speaking of the desire to pose or to post myself in a kind of absolute privatization (but in this case there must no longer be any position that holds). The secret without measure: it does not exclude publication, it measures publication against itself ("Envois" 144; "Envois" 157). 
The narrator later returns to this dilemma of the privé, treating it as the desire for a pure private that deprives itself, that ends in privation. He conjures up the image of a "perverse copyist" who labours "in order to deliver nothing to publicity [à la publicité], absolutely nothing that might be proper (private [privé], secret), in order to profane nothing, if this is still possible." The narrator comments: "The activity of this copyist all of a sudden appears ignoble to me - and in advance doomed to failure" (ibid. 182; 196).

4. The absolute secret is impossible or, at least, gives no pleasure. The narrator speaks of his:

taste for (a-b-s-o-l-u-t-e) secrecy: I can take pleasure only on that condition, from that condition. BUT, secret pleasure deprives [prive] me of the essential. I would like everyone (no, not everyone, the best telescopic soul of the universe, call it God if you wish) to know, to testify, to attend [témoigne, assiste] (ibid. 46; 53).

The pure, absolute secret, the heart of the private, can give no pleasure as a secret, unless it is attested to by a witness, by God. The economy of the pleasure of the secret: the private must in some way be known, witnessed, but not by "everyone," by the public in general. The pleasure in secrecy cannot endure or tolerate absolute privacy.

The narrator goes on to say that the need of the absolute secret for a witness is also "the condition for witnessing [témoignage - or for voyeurism - in principle universal, for the absolute nonsecret, the end of the private life [vie privée] that finally I detest and reject." Witnessing can signal "the end of the private life" but, the narrator adds, "while waiting, the private has to be thrown in" [ du privé il faut en rajouter]. The phrase "has to be thrown in," (en rajouter, to add more, an excessive addition) suggests that the private must in some way be "thrown in," added (as an excess) to witnessing, to publicity and the public. The private 
must always be "thrown in" in some kind of excessive relation with the public. The narrator then insists that while he does "not refuse the absolute publicity of testifying" [la publicité absolue de témoignage], he does "reject the witnesses, certain witnesses" (47 trans. modified; 53). For the narrator, the witness appears to be at once the condition for the secret, the private and the public. The witness is neither simply public nor private and, consequently, appears to threaten the ability to draw any clear and absolute distinction between public and private.

Some pages later, the narrator gives a definition of the post card the p. c., within the question of the public and private:

about p. c., private or public correspondences [correspondances privées ou publiques] (a distinction without pertinence in this case, whence the post card, p. c., half-private half-public, neither one nor the other [mi-privee mipublique, ni l'une ni l'autre] .... (ibid. 62; 70).

In The Other Heading (1991), Derrida accords a similar status to the telephone, which prefigures the "ruin" of totalitarianism since it "no longer leaves in place the limit between public and private [la limite entre le public et le privé], assuming," he adds, "that such a limit was ever rigorous" (43; L'autre cap 44-5). "Envois" is concerned with post cards, with correspondences that are "half-private half-public, neither one nor the other." The narrator insists that in the case of the post card, the "distinction" between public and private is "without pertinence."

When, if ever, is this distinction pertinent? The definition of the p.c. can be seen as a brief history of the rise and fall of disinterest. One could say that for classical discourses of disinterest the distinction between public and private is never pertinent. Disinterest has never been a question of the public or the private, but the problem of the public and the private, of finding a reliable framework to establish the "half-private half public": an ideal equilibrium 
between the subject and the objective world, the not too private and the not too public. But, the narrator qualifies this "half-private half-public," adding that it is "neither one nor the other." Traditional discourses of disinterest collapse when it seems that neither the public nor the private sphere can provide a reliable point of reference to establish a disinterested subject.

The narrator goes on to say, "the public or private [publiques ou privée], that is secret, correspondences," "are unthinkable outside a certain postal technology" (“Envois" 104; "Envois" 114). This seems to reiterate that it is the post card, which is "half-private halfpublic neither one nor the other" which enables, in this case, the public and private "correspondences" to be thought. As if there were a-neither-public-nor-private "public" and "private" which makes the public and the private thinkable, possible. The narrator also suggests that both the public and private correspondences are secret: "the public or private, that is secret, correspondences." How can public correspondences be secret? Is this a question of official secrets, state secrets? Of "public" secrets that are private, hidden, concealed from the public? Two pages later, the narrator refers to that other public state institution, "the secret police" (ibid. 106; 117). He also speaks of "a very determined type of postal rationality, of relations between the State monopoly and the secret of private [privés] messages" (ibid. 104; 114-15). The "secret" is, it seems, neither simply private nor public. In a number of works Derrida associates the public space and the transformation of the traditional notion of the polis with the recent rapid, seemingly inexorable, innovations in the media and tele-communications. In Specters of Marx (1993), he locates this transformation of the "public space" in the aftermath of the First World War:

Let us recall the technical, scientific, and economic transformations that, in Europe, after the First World War, already upset the topological structure of the res publica, of public space, and of public opinion [de l'espace public et 
de l'opinion publique]. They affected not only this topological structure, they also began to make problematic the very presumption of the topographical, the presumption that there was a place, and thus an identifiable and stabilized body for public speech, the public thing, or the public cause [la parole, la chose ou la cause publique], throwing liberal, parliamentary, and capitalist democracy into crisis, as it is often said, and opening thereby the way for three forms of totalitarianism which then allied, fought, or combined with each other in countless ways. Now, these transformations are being amplified beyond all measure today. This process, moreover, no longer corresponds to an amplification, if one understands by this word homogeneous and continuous growth. What can no longer be measured is the leap that already distances us from those powers of the media that, in the 1920s, before television, were profoundly transforming the public space, dangerously weakening the authority and the representativity of elected officials and reducing the field of parliamentary discussions, deliberations, and decisions.

The "powers of the media," he concludes, have transformed, are transforming, the public space and turning politicians into "mere silhouettes, if not marionettes, on the stage of televisual rhetoric" (Specters of Marx 79-80; Spectres de Marx 132-33).

One could almost say that Derrida here is repeating, inhabiting what sounds like the dying vestiges of a classical discourse of disinterest. Arguably, it is already in the 1790 s that a climate of increasing anxiety about the ability of the public space to provide a stable ground for public authority is being expressed through a fear that the powers of spectacle (in the media, in the streets, on the stage, and especially in the new stage technologies of artifice and illusion) were at once divorcing themselves from the subject and seen to be transforming, debasing subjectivity. Before the spectres of Marx, the spectacles of spectres in the writings 
of Burke on the French Revolution, in the popular theatrical productions of the late 1790s and the Parisian show La Fantasmagorie, the figure of the spectre signifies a profound and, ultimately fatal, threat to traditional assumptions about the public and the private, to the project of disinterest as an attempt to mediate between the public and the private spheres. ${ }^{10}$

The difference between Derrida's history of the transformation of the public space in the twentieth century and those anxious and unprecedented signs of transformation in the $1790 \mathrm{~s}$ is that Derrida already recognises that these transformations are in effect the product of an inability to draw a clear and discrete distinction between the public and the private. As he says in The Other Heading, "to take account of these rhythms and these qualitative differences, the porosity of a border between the 'private' and the 'public' [une frontière entre le 'private' et le 'public'] appears more incalculable than ever" (L'autre cap 120, my trans.).

In Politics of Friendship (1994), Derrida makes a point of identifying a certain idea of the foundation and possibility of politics (in this case of Carl Schmitt) with drawing a clear distinction between the public and the private. For Derrida, this impossible distinction is constructed on a number of powerful and pervasive oppositions, such as the singular/ universal, woman/ man and is undone and threatened by, amongst other things, the equivocal effects of the politics of friendship, brotherhood and the sexual difference. Derrida insists that "whenever" the border or frontier [frontière] between the public and private is "threatened, fragile, porous, disputable" [menacée, fragile, poreuse, contestable], a discourse reliant on a good, regular, ordered distinction collapses, falls in ruins [tomber en ruine]. He adds that these threats to the private / public distinction have "intensified and accelerated" in “ 'our times'” (Politiques de l'amitié 107, my trans.). If Derrida repeats a discourse of disinterest, it is a disinterest in ruins, a ruin of the classical projects of disinterest that presume that a clear distinction can be found and maintained between the public and the private spheres. 
5. The narrator/letter writer of "Envois" brings to a close his (or her) scattered, but persistent, remarks around the complex and troubled relationship between the public and the private with a public statement (or confidential aside):

I do not believe in propriety, property [je ne crois pas à la propriété] and above all not in the form that it takes according to the opposition public/private [l'opposition public/privé] (p/p, so be it). This opposition doesn't work [ne marche pas], neither for psychoanalysis ... nor for the post ... nor even for the police ... and the secret circulates with full freedom, as secret you promise I swear [comme secret tu promets je jure], this is what I call a post card (“Envois" 185; "Envois" 199).

The post card, we are reminded, "is neither public nor private" and, without being determined by this opposition, suggests, "the secret circulates with full freedom." Some pages later, the narrator writes, "the secret of the post cards burns - the hands and the tongues --it cannot be kept [le garder], q.e.d. It remains secret [reste secret], what it is, but must immediately circulate [circuler], like the most hermetic and most fascinating of anonymous - and open letters. I don't cease to verify this" (ibid. 188; 203). The secret remains and circulates: it is neither absolutely private nor entirely public. As Derrida says in "Passions" (1992), "the secret belongs no more to the private than to the public" [secret ne relève pas plus du privé que du public] (20; Passions 58). ${ }^{11}$ The secret attests to the impossibility of the autonomy of the private and the totality of the public.

Does the secret, which "circulates" freely when the public/private opposition "doesn't work," ne marche pas (and, one wonders, when, if ever, does it work?), also indicate a certain endurance or resistance of the "private relation" which Lévinas spoke of? Or, it is the case that the secret that remains and circulates puts in question the very propriety of the private? And what are we to make of the narrator's two statements of disbelief: "I do not 
believe in propriety, property, and above all not in the form that it takes according to the opposition public/private" and "I believe in no disinterestedness"? It could be said that classical discourses of disinterest presuppose that there is no one or no thing that is either simply private or public. There is no autonomous private or public totality. This is their starting point, it haunts them: the spectres of disinterest.

\section{The Decision of Interest}

The situation is entangled, not to say equivocal, therefore much more interesting [plus intéressante]. ${ }^{12}$

Is, in Derrida's terms, a responsible and dis-interested decision possible? As I have said, Derrida rarely uses the word disinterest, but he has, on occasion, emphasised the word interest. While he exposes in The Truth in Painting what he sees as the inherent interests of Kantian disinterest, Derrida does not offer an alternative theory of disinterest, a disinterest of "disinterest." If the question of disinterest is addressed to Derrida, should we perhaps be asking not about disinterest but interest? What are Derrida's interests? In the introduction to The Truth in Painting, he says, "what interests" him [ce qui m'intéresse] is what remains "untranslatable" in its "economic performance" (5; La vérité en peinture 5$).{ }^{13}$

Perhaps the most significant reference in Derrida's work to interest occurs in "Psyche: Inventions of the other"(1983-1984) and is repeated in "Force of Law" (1990), when he writes, "the interest of deconstruction, of such force and desire as it may have, is a certain experience of the impossible" [L'intérêt de la déconstruction, de sa force et de son désir si elle en a, c'est une certaine expérience de l'impossible] (Psyché 27; “Force of Law”30). ${ }^{14}$ Derrida's work is interested: it claims a certain, necessary, interest. It takes a decisive interest in "the impossible." 
As an examination of traditional discourses of disinterest in the seventeenth and eighteenth century suggest, disinterest has never been a question simply of asserting, finding or establishing a pure point of disinterest, a complete and absolute non-interest. Such a total absence of interest is more akin to Freud's definition of sleep as the "suspense of interest in the world" (Freud 117). Disinterest has traditionally been driven by trying to find the "most effective" (and perhaps impossible) balance between self-interest and the interests of others, between the demands of subjectivity and the demands of the external world. Disinterest has always been concerned with finding a point of reference or framework either outside or inside the subject upon which to establish a limit or a threshold to self-interest, to the interests of the self. Can "the experience of the impossible" be seen as a condition for a certain disinterest?

What are the interests of Derrida's work?

At the "beginning" of Glas, Derrida places his own interests within the problem of the decision. ${ }^{15}$ At the outset, Derrida has made his choice: "Let me admit - a throw of the d(ie) [coup de dé] - that I have already chosen." He then highlights "the problem of the introduction in/to [à la ] Hegel's philosophy" and "all the difficulties ... that the decision of such a stroke instigates." "I mark the decision" [Je marque la décision], he states. And, "even before analyzing" the key terms of the family, civil society and the state in Hegel's Philosophy of Right, he says, "we see the stake and the interest [on voit l'enjeu et l'intérêt] of this familial moment" (Glas 3-4; Glas 9-10). Before analysis, "the interest" is already apparent. But what is (this) interest? How do "we see" it?

Derrida implies in Glas that interest is concerned with "the whole Hegelian determination of right $[$ droit $]$ on one side, of politics on the other." Interest and the decision circulate here through questions of "the active movement of penetration," "an active interpretation," the inability to decipher and still "be neutral, neuter, or passive." He goes on to write, "What always remains irresoluble, impracticable, nonnormal, or nonnormalizable is what interests 
and constrains us here [ce qui nous intéresse et nous contraint ici]. Without paralyzing us but while forcing us on the course" [à la demarche] (ibid. 4-5; 10-11). Derrida suggests "what interests" also "constrains," that interest - in the "irresoluble, impracticable, nonnormal" - is a kind of constraint. This constrained interest is not a paralysis, though it has its own force. For Derrida, it seems that this interest and constraint is decisive. But decisive for whom or for what? Do we choose what interests us, especially when our interest is in "what always remains irresoluble"? How can one be decisive about the impossible, the irresoluble?

Lévinas argues that any radical idea of disinterest must preclude a decision. "The responsibility for the other," he writes in Otherwise than Being (1974), "can not have begun in my commitment, in my decision." Disinterestedness, "the exposure to another" to "the point of substitution," is "prior to any voluntary decision." Disinterest is "an obsession despite oneself' (Otherwise than Being 10, 54-5). Dés-intéressement can never be decisive. For Derrida, on the other hand, from his earliest essays, the decision, the responsible decision, has played a key role in his thoughts on the aporia in ethics and politics. Nonetheless, like Lévinas, Derrida insists that a responsible decision is never decisive, in the sense that it confirms or reflects the active, voluntary power of the subject to anticipate and achieve a decision. As he writes in Politics of Friendship, "the decisive moment" ceases, the "instant" that it is taken to "follow the consequences of this which is, that is to say, of this which is determinable." The responsible decision by the subject is always "an other decision," passive, unconscious: "an agonising [déchirante] decision as decision of the other" (Politques de l'amitié 87-8, my trans.). A responsible decision by the subject is always a decision of the other: a "decision of the other in me"[l'autre en moi] (208). As Derrida remarks in Adieu, "the decision and the responsibility are always from the other" [de l'autre]. It is, he notes, in the attempt to put in question the "traditional determination and 
massive domination of the subject" that he has insisted, "a theory of the subject is incapable of giving an account of the slightest decision" [la moindre décision] (52 n.2, my trans.).

For Derrida, a decision is an unavoidable, agonising experience of finitude. The decision is marked by "an anguished experience of imminence" (The Other Heading 5). It is a moment of crisis, a moment of "performative and ... interpretative violence" (The Other Heading 31-2; "Force of Law"13). The "moment of decision, as such," Derrida writes, "always remains a finite moment of urgency and precipitation ... The instant of decision is a madness [L'instant de la décision est une folie], says Kierkegaard" ("Force of Law" 26; Force de loi 58). It is worth noting that Derrida first quoted this phrase from Kierkegaard some thirty years earlier in 1963 as an epigraph to his essay "Cogito and the History of Madness."

Faced by two contradictory certainties, the decision appears within the "dreadful fatality of a double constraint" (Adieu 66, my trans.). However, Derrida adds,

the undecidable is not merely the oscillation or the tension between two decisions; it is the experience of that which, though heterogeneous, foreign to the order of the calculable and the rule, is still obligated --it is of obligation [devoir] that we must speak - to give itself up to the impossible decision, while taking account of laws and rules. A decision that didn't go through the ordeal [l'épreuve] of the undecidable would not be a free decision, it would only be the programmable application or unfolding [le déroulement] of a calculable process ("Force of Law" 24; Force de loi 53).

This "ordeal of the undecidable" or, as Derrida says elsewhere, "a sort of nonpassive endurance of the aporia," is "the condition of responsibility and of decision"(Aporias 16). An irresponsible decision, on the other hand, is a decision that is clear from the start and in effect "already made" [déjà prise] and, consequently, is nothing more than the 
implementation or elaboration (déroule, the progressive unwinding) of a programme (The Other Heading 41, 45; L'autre cap 43, 46). ${ }^{16}$ The possibility of a responsible decision must endure "a kind of necessarily double obligation, a double bind," the impossible, the undecidable (The Other Heading 29; L'autre cap 33).

In The Other Heading, Derrida observes "there is no responsibility that is not the experience of the impossible" (44, trans. modified). No responsibility, he writes elsewhere, "could ever be taken [être prise] without equivocation and without contradiction" (my emphasis) ("Passions" 9; Passions 25). It is only because I am faced with an anguished contradiction, with impossible demands, that I can and must, in an instant, take a decision, a responsible decision - a decision which is "like a gift from the other" (Politiques de l'amitié 88, my trans.). It is the heterogeneous time of "an indecision from which alone a responsibility or a decision must be taken" [ne décision doivent être prises] (Adieu 201, my trans.). As Derrida remarks, "Justice is an experience of the impossible" and "incalculable justice requires us to calculate" [la justice incalculable commande de calculer] ("Force of Law” 16, 28; Force de loi 38, 61).

Derrida has said, "the interest of deconstruction, of such force and desire as it may have, is a certain experience of the impossible" (my emphasis). Justice, responsibility and the decision, the responsible decision, are all conditioned by "a certain experience of the impossible." What then is the relation, if any, between the responsible decision that is (un)conditioned by the impossible and the interest that Derrida's thought has in the "experience of the impossible"? In The Other Heading he writes, "For the moment, it is the word "capital," more precisely the tenor of its idiom, that must interest us in order to justify the reference to Valery." "For the moment," he says, "pour l'instant" - "l'instant de la decision" - it is the word "capital" (which of course has its own interest in interest), "that must interest us" (que nous devons nous intéresser). In other words, he implies that for the 
moment, at this moment, an instant of decision, we must take an interest (The Other Heading 57; L'autre cap 58). ${ }^{17}$ To make a responsible decision, we must take an interest.

As the opening of Glas suggests, many of Derrida's works start by highlighting the contradictory, strategic and decisive moment of madness when an interest is taken. No matter how agonising, how mad, how risky, an interest must be taken. It must be decisive in its inevitable indecisiveness. Above all, it must have an interest in the "experience of the impossible," in the responsibility "for the other before the other" (de l'autre devant l'autre) (Politques de l'amitié 87-8, my trans.). ${ }^{18}$ An interest must be taken (doivent être prises). Derrida insists that his work is "anything but a neutralization of interest in justice" [ $d e$ l'intérêt pour la justice] ("Force of Law" 20; Force de loi 45).

One must take a decision of interest in "a certain experience of the impossible." Can this decisive interest in the experience of the impossible be described as a certain dis-interest? If the decision is conditioned by the undecidable, is interest (an interest in the impossible) conditioned by dis-interest (by a certain dis-interest that, as "every responsible decision," "must run" the "absolute risk" of avoiding "good conscience at costs") (Aporias 19)? Is the decision of interest a dis-interest of the subject? As I take an interest (in the impossible) am I taken away from myself, by the other, for the other?

As far as I am aware, Derrida has yet to take such a decision of interest in disinterest. There is, however, a hint of such a decision in the last chapter of Given Time (1992) that brings together or entangles the motifs of unconditionality, the decisive instant of decision and disinterest:

the condition common to the gift is a certain unconditionality ... The event and the gift, the event as gift, the gift as event must be irruptive, unmotivated - for example, disinterested [doivent être irruptifs, immotivés - par exemple désintéressés]. They are decisive and they must therefore tear the fabric, 
interrupt the continuum of a narrative [récit] that nevertheless they call for, they must perturb the order of causalities: in an instant (123; Donner le temps 157).

Disinterest appears here as an "example" of an unmotivated irruption, an irruption without motive.

On the one hand, while Derrida may have little to say about disinterest, he has a lot to say about interest. For example, in Given Time there are many kinds of interest, including: "the most interesting idea, the great guiding thread"; the "operation of exchange with interest"; "interest rates"; "an interest of the thing itself" (40-2); "capitalized interest" (97); "the real interest of a true wealth"; "interest without labor" (124); "an interesting coincidence"(129); "the common interest" (139, trans. modified); "the most powerful and most interesting speculation"(151); "the game of interest"(156). A narrative of (dis)interest could perhaps be constructed through tracing the decisions of interest in Derrida's texts, the decision that is taken when something "here must interest us" [doivent ici nous intéresser] (Politiques de l'amitié 104, my trans.).

Why is this or that word, idea, question, problem, text, rather than another word or text interesting? Why and at what moment does something, some text, some one, elicit or demand interest - become "the most interesting" (la plus intéressante)? When is interest Derrida's own interest and when and how can it be shared? In Politics of Friendship, he writes, "anyone can interest themselves [peut s'intéresser] in the problems that we are tackling here" (302, my trans.). What is the gift of interest? Is it - irruptive, unnmotivated a kind of dis-interest? Is such a narrative of (dis)interest possible? At the end of Given Time, Derrida warns, "the interest" [l'intérêt $]$ of Baudelaire's text, "like any analogous text in general, comes from the enigma constructed out of this crypt which gives to be read that which will remain eternally unreadable, absolutely indecipherable, even refusing itself to any 
promise of deciphering or hermeneutic" (152; Donner le temps 193). For Derrida, this is principally a matter of "the secret of literature," but it is also a question of the secret of (dis)interest and the spectres of the private and the public that haunt all discourses of disinterest.

On the other hand, by taking an interest, has Derrida not already taken up some of the remnants of the traditional discourses of disinterest? In "Force of law," through a reading of Pascal, he refers to "a critique of juridical ideology, a desedimentation of the superstructures of law [droit] that both hide and reflect the economic and political interests [intérêts] of the dominant forces of society"(my emphasis) ("Force of Law" 13; Force de loi 32). He is even more emphatic when in Specters of Marx he writes, "Deconstruction has never had any sense or interest [d'intérêt], in my view at least, except as a radicalization, which is to say also in the tradition of a certain Marxism, in a certain spirit of Marxism." A few pages later, he adds that he is concerned with, "the interest [l'intérêt], and first of all the interest [l'intérêt] of capital in general, an interest [un intérêt] that, in the order of the world today, namely the world-wide market, holds a mass of humanity under its yoke and in a new form of slavery" (Specters of Marx 92.94; Spectres de Marx 151, 155). To identify and challenge interests, hidden interests, the interests of the subject in itself (self presence, chez soi), its interests in the other, the interests of capital, interests "in general," is this not the first gesture of disinterest? Derrida's decisive, difficult and agonising interest that must be taken from "the experience of the impossible" is, perhaps, since Lévinas's dés-intéressement, the most provocative reworking of disinterest - of, as he would say, a disinterest $\grave{a}$-venir, to come. ${ }^{19}$ 


\section{Notes}

${ }^{1}$ I will refer to both the English translation and French original of Derrida's works. In a number of cases, I have used my own translations. Details of the published translation can be found in the bibliography.

${ }^{2}$ On Lévinas's reworking of disinterest, see my forthcoming article "Lévinas, Disinterest and Enthusiasm," in Literature and Theology.

3 The quote is from Chalier, Figures du feminine.

${ }^{4}$ See also, Donner le mort 71.

5 Derrida is most likely referring to Beyond Good and Evil $§ 220$, in which Nietzsche states "the naked truth, which is surely not hard to come by, [is] that the "disinterested" action is an exceedingly interesting and interested action" [dass die "uinteressirt" Handlung eine s e $\mathrm{hr}$ interessante und interessirte Handlung ist] and goes on to write, "anyone who has really made sacrifices [wirklich Opfer gebracht hat] knows that he wanted and got something in return - perhaps something of himself in return for something of himself" [vielleicht etwas von sich für etwas von sich] (338-39; Jenseits von Gut und Böse160). Derrida returns to the question of an economy of disinterested sacrifice in his reading of Donner la mort (143).

${ }^{6}$ It can also be said that Kant's claim for disinterested "subjective universality," like the final revisions in Adam Smith's Theory of Moral Sentiments published the same year, marks an important shift in discourses of disinterest by suggesting that the subjective world can legitimate common standards for disinterested judgement.

7 See also, "Econmimesis" 76-77, 90.

${ }^{8}$ For the reference to Lévinas see, "Force of Law" 22; Force de loi, 48-9.

${ }^{9}$ One of the earliest occurrences of the word disinterest in English appears in Francis Bacon's The Charge Touching Duels (1612). For Bacon, in "private duels" "private men begin once to presume to give law to themselves" and this can lead to the state becoming "a distempered and unperfect body, continually subject to inflammations and convulsions." The first remedy Bacon suggests is for the "state to abolish it." The would-be duellist will then 
"see the law and rule of state disinterest him of a vain and unnecessary hazard"(307).

Disinterest is used here as a verb, denoting "to rid or divest of interest"(O. E. D.).

${ }^{10}$ I have explored the spectacles of spectres in the 1790s in more detail in a forthcoming article, "Romanticism and the Spectres of Disinterest," in the European Romantic Review.

11 See also, Aporias 85, n. 10; Spectres of Marx 50.

12 Donner le mort 73.

${ }^{13}$ Derrida makes a number of passing references in this period to "what interests" him in "Restitutions" (in The Truth in Painting) 279, 282, 293, 314, 331, 334, 352, 367 and in "To Speculate - on 'Freud' "' (in The Post Card) 304, 322, 325, 338, 385.

${ }^{14}$ In "Psyché: invention de l'autre," the original sentence from which this phrase is taken reads:

L'intérêt de la déconstruction, de sa force et de son désir si elle en a, c'est une certaine expérience de l'impossible: c'est-à-dire, j'y ferai retour à la fin de cette conférence, de l'autre, l'expérience de l'autre comme invention de l'impossible, en d'autres termes comme la seule invention possible.

In the published English version of "Force of Law" (1992), this phrase is found at the end of a quotation from "Psyché" in the main body of the text (30). In the French edition of Force de loi (1994), the quotation has been altered slightly and placed in a footnote (78, n. 1).

15 See also, Glas on Hegel's interest (75; 88) and on interest of Kant $(216 ; 242)$.

16 The translators of L'autre cap render "déroule un programme" as "elaborates a program."

${ }^{17}$ In The Other Heading this passage is translated as: "For the moment, we must focus our attention on the word "capital' " (57). The phrase "nous devons nous intéresser" has become "we must focus our attention."

${ }^{18}$ Derrida later writes, "One responds before [devant] the other because first one responds to $[\grave{a}]$ the other" (282, my trans.). 
${ }^{19}$ Derrida notes in Politiques de l'amitié that the to-come [l'à-venir], comes apart, loosens, dis-joins itself [se disjoint] and "it dis-joins [disjoint] the self [le soi] that would still like to join itself, put itself together [s'ajointer] in this disjunction" (58, my trans.). I would like to thank Viviane de Charrière, Peter Otto, David L. Clark and Carmella Elan-Gaston

\section{Bibliography}

Bacon, Francis. "The Charge Touching Duels." Francis Bacon. Ed. Brian Vickers. Oxford; Oxford UP, 1996. 304-13.

Chalier, Catherine. Figures du féminin: lecture d'Emmanuel Lévinas. Paris: La nuit surveillée, 1982.

Derrida, Jacques. Adieu: à Emmanuel Lévinas. Paris: Galilée, 1997. Trans. Pascale-Anne Brault and Michael Nass. Adieu: To Emmanuel Levinas. Stanford: Stanford UP, 1999. . L'autre cap. Paris: Minuit, 1991. Trans. Pascale-Anne Brault and Michael B. Nass. The Other Heading. Bloomington: Indiana University Press, 1992. . Apories. Paris: Gailée, 1996. Trans. Thomas Dutoit. Aporias. Stanford: Stanford

UP, 1993.

. "Cogito and the History of Madness." Writing and Difference. Trans. Alan Bass. Chicago: U of Chicago P, 1989. 31-63. . Donner le mort. Paris: Galilée,1999. . Donner le temps: I. La fausse monnaie. Paris: Galilée,1991. Trans. Peggy Kamuf. Given Time: 1. Counterfeit Money. Chicago: U of Chicago P, 1992. . "Economimesis." Mimesis: des articulations. Paris: Aubier-Flammarion, 1975. 56-93. Trans. Richard Klein, “Economimesis.” Diacritics11 (1981): 3-25. 
. "En ce moment même dans cet ouvrage me voici." Psyché: inventions de l'autre. Paris: Galilée, 1987. 159-202. Trans. Ruben Berezdivin. “At This Very Moment in This Work Here I am.” Re-Reading Lévinas. Ed. Robert Bernasconi and Simon Critchley. Bloomington: Indiana UP, 1991. 11-48.

. "Envois." La carte postale: de Socrate à Freud et au-delà. Paris: Aubier Flammarion,1980. 5-273. Trans. Alan Bass. "Envois." The Post Card: From Socrates to Freud and Beyond. Chicago: U of Chicago P, 1987. 1-256.

. "Le fins de l'homme.” Marges de la philosophie. Paris: Minuit, 1972. 129-

166. Trans. Alan Bass. "The Ends of Man." Margins of Philosophy. Chicago: U of Chicago P, 1990. 109-136.

. Force de loi: Le "Fondement mystique de l'autorité." Paris: Galilée, 1994.

Trans. Mary Quaintance. "Force of Law: 'The Mystical Foundation of Authority'." Deconstruction and the Possibility of Justice. Ed. Drucilla Cornell, Michael Rosenfeld, David Gray Carlson. New York: Routledge, 1992. 3-67.

. Glas. Paris: Galilée, 1974. Trans. John P. Leavey Jr., and Richard Rand, Glas. Lincoln: U of Nebraska P, 1990.

. "Parergon." La vérité en Peinture. Paris: Flammarion, 1978. 21-168. Trans.

Geoff Bennington and Ian McLeod. "Parergon.”The Truth in Painting. Chicago: U of Chicago P, 1989. 15-147.

. "Passe-Partout." La vérité en Peinture. Paris: Flammarion, 1978. 5-18. Trans.

Geoff Bennington and Ian McLeod. "Passe-Partout." The Truth in Painting. Chicago: U of Chicago P, 1989. 1-13.

. Passions. Paris: Galilée, 1993. Trans. David Wood. "Passions: 'An Oblique

Offering'," Derrida: A Critical Reader. Oxford: Blackwell, 1992. 5-35

. "La pharmacie de Platon.” La dissémination. Paris: Seuil, 1972. 69-167.

Trans. Barbara Johnson, “Plato's Pharmacy.” Dissemination. Chicago: U of Chicago P, 1981. 61-171. 
. Politiques de l'amitié. Paris: Galilée, 1994. Trans. George Collins. Politics of Friendship. London: Routledge, 1997.

. "Psyché: invention de l'autre." Psyché: Inventions de l'autre. Paris: Galilée, 1987. 11-61. Trans. Catherine Porter. "Psyche; Inventions of the Other." Reading de Man Reading. Ed. Lindsay Walters and Wlad Godzich. Minneapolis: U of Minnesota Press, 1989. 25-66.

. "Le puits et la Pyramide: introduction à la sémiologie de Hegel." Marges de la philosohie. Paris: Minuit,1972. 79-128. Trans. Alan Bass. "The Pit and the Pyramid: Introduction to Hegel's Semiology." Margins of Philosophy. Chicago: U of Chicago P, 1990. 69-108.

. "Les pupilles de l'Université: Le principle de raison et l'idée de l'Université." Du droit à la philosophie. Paris: Galilée, 1990. 461-98. Trans. Catherine Porter and Edward P. Morris. "The Principle of Reason: The University in the Eyes of its Pupils." Diacritics 13 (1983): 3-20.

. "Restitutions - de la vérité en pointure." La vérité en Peinture. Paris: Flammarion,1978. 291-436. Trans. Geoff Bennington and Ian McLeod. "Restitutions of the truth in pointing." The Truth in Painting. Chicago: U of Chicago P, 1989. 255 382.

. Spectres de Marx. Paris: Galilée, 1993. Trans. Peggy Kamuf, Specters of Marx London: Routledge, 1994.

. “Spéculer - sur 'Freud' ." La carte postale: de Socrate à Freud et au-delà. Paris: Flammarion,1980. 275-437. Trans. Alan Bass. "To Speculate - on 'Freud' ." The Post Card: From Socrates to Freud and Beyond. Chicago: U of Chicago P,1987. 259-409.

. "Violence et métaphysique: essai sur la pensée d'Emmanuel Lévinas." L'écriture et la difference. Paris: Seuil, 1967. 117-228. Trans. Alan Bass. "Violence and Metaphysics: an essay on the Thought of Emmanuel Lévinas." Writing and Difference. Chicago: U of Chicago P, 1989. 79-153. 
Freud, Sigmund. Introductory Lectures on Psychoanalysis. Trans. James Strachey. London: Penguin, 1991.

Hegel, G. W. F. Science of Logic. Trans. A. V. Miller. London: Oxford UP, 1969.

Hyppolite, Jean. Genesis and Structure of Hegel's Phenomenology of Spirit. Trans. Samuel Cherniak and John Heckman. Evanston: Northwestern UP, 1989.

Kant, Immanuel. The Critique of Judgment. Trans. James Creed Meredith. Oxford: Oxford UP,

1952.

Lévinas, Emmanuel. "Dieu et la philosophie.” De Dieu qui vient à l'idée. Paris: Vrin, 1998. 93-127. Trans. Bettina Bergo, Of God who comes to Mind. Stanford: Stanford UP, 1998.

. Otherwise than Being or Beyond Essence. Trans. Alphonso Lingis

Pittsburgh: Duquesne UP, 2000.

. Totality and Infinity: An Essay on Exteriority. Trans. Alphonso Lingis.

Pittsburgh: Duquesne UP, 1996.

Nietzsche, Friedrich. Jenseits von Gut und Böse. Nietzche Werke. Vol. VI. Ed. Giorgio Colli and Mazzino Montinari. Berlin: Walter de Gruyter, 1968. Trans. Walter Kaufman. Beyond Good and Evil. Basic Writings of Nietzsche. New York: Modern Library, 1968.

Poe, Edgar Allan. "The Purloined Letter." The Fall of the House of Usher and Other Writings. Ed. David Galloway. London: Penguin, 1986. 330-49. 